REVIEWS

\title{
Molecularly imprinted polymers as synthetic mimics of biorteceptors. 1. General principles of molecular imprinting.
}

\author{
T.A.Sergeyeva
}

Institute of Molecular Biology and Genetics, 150 Zabolotnogo str., 03680, Kiev, Ukraine.

t_sergeyeva@yahoo.co.uk

The review is devoted to analysis of the publications in the area of synthesis of artificial mimics of biological receptors using the method of molecular imprinting. General principles of molecular imprinting as well as main types of polymers being used in molecular imprinting are described. The special attention is paid to the polymers-biomimics synthesized using the method of non-covalent molecular imprinting.

Keywords: molecular imprinting, molecularly imprinted polymer, polymers-biomimics.

The ability of living cells to obtain information from external environment is based on molecular recognition phenomenon. Regulation of virtually all biochemical processes in living organisms is associated with molecular recognition based on complementarity of biomolecules: enzymatic catalysis, intracellular transport, interaction of hormones and other mediators with their receptors, and antigen-antibody interactions. In

(C) Institute of Molecular Biology and Genetics NAS of Ukraine, 2009 other words, molecular recognition is a fundamental principle of life.

Unique selectivity of biomolecules provides their wide practical applications - for the development elaboration of analytical methods and biotechnological processes as well as in medical diagnostics. Normally natural receptors interact with the corresponding ligands with high affinity, however, under non-physiological conditions they are very unstable. Unfortunately, all biomolecules are extremely sensitive to changes of temperature, $\mathrm{pH}$, [the] presence of organic solvents, toxins, heavy metals, etc. The general draw- 

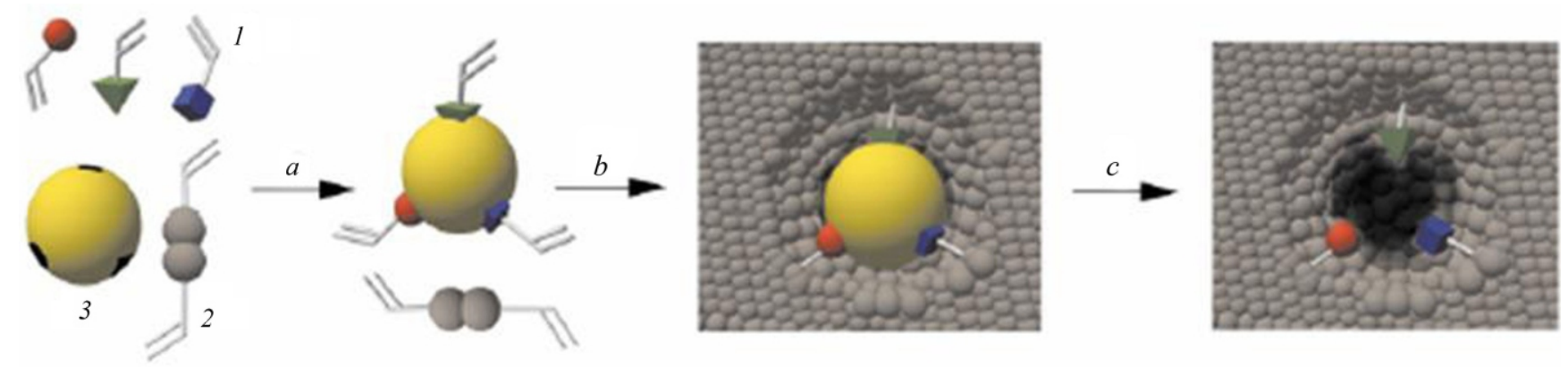

Fig. 1. The main principle of molecular imprinting. $a$. A template molecule (3) forms a complex with functional monomers (1) in a solutioni. $b$. Polymerization in the presence of a cross-linker (2). $c$. Extraction of the template and formation of synthetic binding sites complementary to the template in their shape and arrangement of functional groups.

backs of all biomolecules, limiting their wide practical application, are complicated procedures of their isolation and purification as well as high cost. Possibilities of getting natural receptors in preparatory quantities are often limited. Moreover, not all the molecules of interest have their natural receptors.

Synthesis of artificial receptors able to recognize and bind different target molecules with high affinity and specificity is a topical problem of current biotechnology, analytical biochemistry, and medicine. Ideally, these materials are to combine the ability of bioreceptors to recognize corresponding analytes selectively with stability, easy synthetic procedure, and low cost.

During recent years molecularly-imprinted polymers (MIPs or so-called polymers-biomimics), mimicking active sites of antibodies and biological receptors, have attracted significant attention [1]. They can provide high selectivity [2-4], while the method of their synthesis is quite simple. Normally, they demonstrate sufficient thermal and mechanical stability, as well as stability in aggressive media [5]. Therefore, polymers-biomimics combine high selectivity of biomolecules with the stability of synthetic polymers in harsh environments.

The method of molecular imprinting [1] is widely used for the synthesis of polymers-biomimics. It assumes formation of highly cross-linked polymers around so-called template molecules. The synthesis takes place due to co-polymerization of functional and cross-linking monomers in the presence of template molecule (the template molecule is at the same time an analyte of interest). Extraction of the template molecules from the fully-formed polymeric network results in formation of cavities, which [are complementary to the template] in their size, shape, and spatial arrangement of functional groups are complementary to the template. The molecularly imprinted polymers synthesized according to this principle are able of further selective binding the template molecules (Fig. 1).

The complex between functional monomers and templates can be formed under participation of both reversible covalent and noncovalent (hydrogen, ionic, hydrophobic, van der Waals) interactions. The method of covalent imprinting, proposed by Wulff and co-authors [6-13], assumes synthesis of the template molecule derivative, capable of polymerization. After the synthesis of the covalent molecularly-imprinted polymer, the template molecule is to be removed through cleavage of the covalent bonds between the template and functional monomers. Application of this method has significant limitations in selection of potential template molecules, while kinetics of their binding by the polymers is quite slow. However, a significant advantage of this approach as compared to the non-covalent one is formation of more homogeneous (in terms of affinity) population of binding sites.

More universal approach to the synthesis of molecularly-imprinted polymers was proposed by Mosbach and co-authors [14-18]. According to the non-covalent approach, formation of the complex template-functional monomer takes place due to non-covalent interactions. This approach is more flexible as compared to the covalent one, since the choice 
of templates and functional monomers is virtually unlimited, while the template molecules can be easily extracted from the polymer by the corresponding organic solvent. It is widely recognized that the non-covalent molecularly-imprinted polymers contain heterogeneous (in terms of affinity towards the template molecule) population of synthetic binding sites, which is often compared to populations of polyclonal antibodies $[19,20]$.

Vulfson et al. demonstrated a possibility of synthesis of hybrid materials, where interaction of a template with functional monomers takes place due to both covalent and non-covalent interactions [21].

Since the approach based on non-covalent imprinting is more universal for the synthesis of artificial analogues of biomolecules, the main attention in the present review is focused on the molecularly-imprinted polymers, synthesized according to this principle.

Template molecules. The special feature of molecularly-imprinted polymers is the possibility of their synthesis towards virtually unlimited number of substances. Most of papers in the area of molecular imprinting describe synthesis of polymers for selective recognition of small organic molecules (medicines [22-24], drugs [25-28], herbicides [29-36], toxins [37-40], enzyme co-factors [41, 42], amino acids [43-45], nucleotides [46-49], hormones [50-54], sugars [55, 56], dyes [57-59], aromatic substances [60-64], etc.). A number of papers describe imprinting of metal ions [65-72]. During recent years the publications reporting [on] synthesis of molecularly-imprinted polymers for selective recognition of peptides [73-78], proteins [79-84], and even cells [85-88] as well as mineral crystals [89-90] have appeared. However, imprinting of high-molecular weight substances is still problematic.

To be successfully used as a template, a substance is to be stable under polymerization conditions $\left(\mathrm{t}=60-80^{\circ} \mathrm{C}, \mathrm{UV}\right.$-irradiation), and it is not supposed to contain groups inhibiting/able to take part in polymerization.

Types of the polymers used in molecular imprinting. The structure of a polymeric matrix is crucial in molecular imprinting, since it determines selec- tivity of synthetic binding sites in resulting polymers. The latter are to fulfill the following requirements [1]:

1) the polymer is to be highly cross-linked so that selective sites retain their shapes after removal of the template molecules,

2) certain flexibility of polymer chains, which for the first site contradicts high degree of cross-linking, is necessary for fast kinetics under [the] binding of template molecules,

3) as many as possible synthetic binding sites are to be accessible for the interactions with template molecules,

4) the polymer is to be mechanically stable, which is crucial requirement in the case of its application in harsh environments (i.e. organic solvents), HPLC or SPE under increased pressures, in industrial reactors under constant stirring, etc.

5) thermal stability is essential in the case of MIPs application under increased temperatures, that are favorable for better kinetics.

The main types of the polymers that are being used in molecular imprinting are organic polymers, composite materials consisting of thin layers of organic polymers on/in inorganic carriers, silica gels, and biopolymers.

Organic polymers. Most of molecularly-imprinted polymers are macroporous acrylate or vinyl polymers. That is determined by the wide spectrum and availability of the monomers for their synthesis. Macroporous organic polymers are synthesized by radical co-polymerization of functional and cross-linking monomers in the presence of template molecules and inert solvents (porogens). Macroporous polymers are formed in the case of a high content (up to 90-95\%) of cross-linker in the initial monomer composition. Further polymerization leads to phase separation resulting in formation of permanent pore structure. The most widely used functional monomers for the synthesis of molecularly-imprinted polymers are summarized in Fig. 2.

Formation of stable template-functional monomer complexes is crucial in the technique of molecular imprinting. Normally, formation of stable complexes with template molecules in non-covalent MIPs is 
<smiles>C=CC(=O)NC(C)(C)CS(O)(O)O</smiles><smiles>C=CC1CCNCC1</smiles><smiles>C=CC(=O)O</smiles>

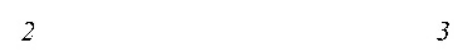<smiles>C=CCNC</smiles>

5<smiles>CC(CC(=O)O)C(=O)O</smiles>

9<smiles>C=Cc1ccccc1</smiles>

13<smiles>CC(C(=O)O)C(F)(F)F</smiles>
17<smiles>C=CC(=O)C=O</smiles><smiles>O=C(O)C=Cc1c[nH]cn1</smiles>

14<smiles>C=C(C)C(=O)OCCO</smiles>

18

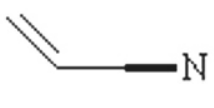

22<smiles>C=Cn1ccnc1</smiles><smiles>C=C(C)C(=O)O</smiles>

12<smiles>C=Cc1ccccn1</smiles>

15<smiles>C=CC=O</smiles>

19<smiles>C=Cc1ccncc1</smiles>

23

Fig. 2. Functional monomers used in molecular imprinting: 1 - (2-acrylamido-2-methyl-1-propanesulfonic acid), 2 - 4-vinylpyridine, 3 acrylic acid, 4 - vinylimidazole, 5 - allylamine, 6 - p-divinylbenzene, 7 - ethyleneglycoldimethacrylate, 8 - urocanic acid ethyl ester, 9 itaconic acid, 10 - m-divinylbenzene, 11 - N,N'-methylenebisacrylamide, 12 - methacrylic acid, 13 - styrene, 14 - urocanic acid, 15 2-vinylpyridine, 16 - diethylaminoethylmethacrylate, 17 - 2-(triftormethyl)acrylic acid, 18 - hydroxyethylmethacrylate, 19 - acroleine, 20 acrylamide, 21 - acrylic acid, 22 - acrylonitrile, 23 - 4- vinylpyridine. 
achieved under excess of functional monomers in the initial monomer mixture. This shifts the equilibrium to formation of the complexes. It is widely known that due to exothermic nature of the polymerization reaction as well as possible structural changes of both template and functional monomers, the structure of a part of these complexes will be changed or destroyed. The number of "defect" sites can decrease in the case of formation of strong complexes between templates and functional monomers. Therefore, selection of functional monomer is of great importance, since it influences directly the affinity and selectivity of a molecularly-imprinted

polymer.

Most of scientists chose functional monomer taking into account just general considerations [90-93]. Some papers describe application of combinatorial approach to MIP synthesis and functional monomer selection [94-96]. The authors synthesized MIP libraries, where the type of functional monomer and a ratio template:functional monomer were varied in the initial monomer mixture. That was followed by [the] screening of the resulting MIPs as for their ability to recognize template molecules selectively. Using this approach, compositions of the polymers able to recognize selectively triazine herbicide terbutylazine [95], phenytoin, and nifedipine [92] were optimized. Despite the fact that every MIP from the library was synthesized in small quantity, the approach itself is laborious and time-consuming, which significantly limits its application.

Significantly more effective approach to optimization of MIP compositions (selection of functional monomers able to form strong complexes with template molecules) was proposed by the other authors [38, 40, 97-99]. The method provides a possibility of fast preliminary screening [of] a large number of potential functional monomers, while [the] results of the screening of a virtual library of functional monomers correlate with [the] experimental data on binding template molecules with computational MIPs. Moreover, [an] analysis of [the] computational modeling data as for formation of complexes template-functional monomer gives a possibility to synthesize materials capable of both highly-selective recognition of individual substances and recognition of groups of substances with similar structures $[39,40]$. Up to now, this approach is the most promising, since significantly decreases time losses for optimization of MIP composition. At the same time, it gives information as for possible structure of template-selective binding sites in polymers-biomimics.

The effect of molecular imprinting is based on rigid fixation of template-functional monomer complexes in a polymeric network, which provides a desired spatial arrangement of functional groups of the monomers and, as a result, of a whole synthetic binding site. As it was mentioned, that is achieved by addition of $90-95 \%$ of bi/three-functional cross-linkers in the initial monomer composition. The most widely used cross-linkers in non-covalent molecular imprinting are ethyleneglycol dimethacrylate, trimethylolpropane trimethacrylate, n-divinylbenzene, N,N'-bisacrylamide (Fig. 3).

The numerous investigations demonstrate that ethyleneglycol dimethacrylate is the cheapest cross-linker, resulting in synthesis of MIPs with optimal properties. It provides high selectivity under separation of enantiomers and structural analogues [100-102], while chromatographic columns based on these polymers don't loose their selectivity under constant use at $80^{\circ} \mathrm{C}$ and pressure $6-10 \mathrm{MPa}$ for months [103]. Therefore, most of research groups use ethyleneglycol dimethacrylate-based polymers for the purposes of selective binding [104-108]. In recent years synthesis of MIPs based on polyphenol [109], polyaminophenylboronic acid [110], co-polymer of poly(phenylenediamine) with aniline [111], polyuretanes [63], and oxidized polypyrroles [112, 113] was reported.

Organic polymers on/in inorganic carriers. Thin $(5-10 \mathrm{~nm})$ layers of macroporous polymers having the structure similar to those described in the section "Organic polymers" can be synthesized on the surface of macroporous silica-gels. That is achieved by covalent attachment of methacrylate groups to the silica surface through reaction with 3-(trimethoxysilyl)propylmethacrylate. That is followed by initiation of the radical polymerization of monomers traditionally used in molecular imprinting on the surface of silica-gels. Using this approach one can obtain polymeric adsorbents, which don't swell in organic solvents and aqueous solutions. These materi- 


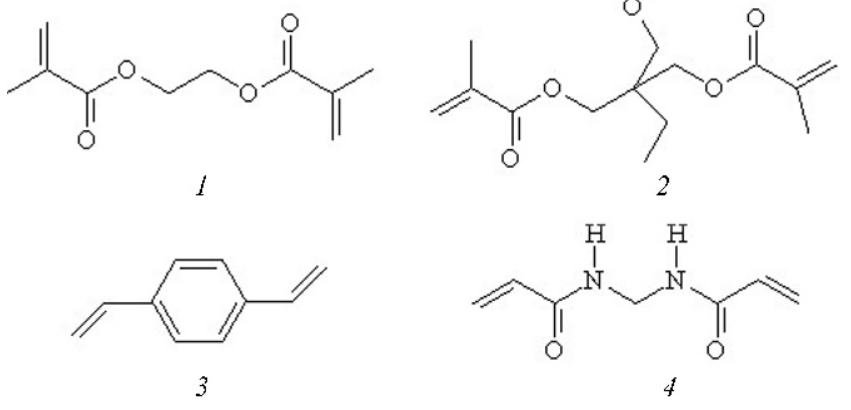

Fig. 3. Cross-linkers used in noncovalent molecular imprinting: 1 ethyleneglycoldimethacrylate, 2 1,1,1,-trimethylolpropanetrimethacrylate, 3 - p-divinylbenzene, 4 $\mathrm{N}, \mathrm{N}$ '-methylenebisacrylamide.

als are mainly used for chromatographic separation of enantiomers $[17,114,115]$ and close structural analogues [29], as well as in solid-phase extraction [116].

Since surface modification of inorganic materials is of great importance from the point of view of sensor technology, that is of special interest. A number of papers report surface modification of glass, gold, and tin dioxide [98, 117-126]. The paper [117] describes modification of glass surfaces with self-assembled MIP layers. Monolayers of trichloro- $n$-octadecylsilane were formed on glass surfaces in the presence of a detergent-modified dye as a template molecule. Extraction of the template molecules resulted in appearance of cavities, formed by poly-condensed silane molecules. The MIP monolayers were capable of predominant adsorption of the template as compared to its structural analogues. Unfortunately, the recognition process was too slow, since mass transfer took place through the layer of long-chain alkylsilanes. Amphiphylity of molecules is of great importance in this approach. The re-adsorption process was investigated electrochemically [119], using Raman spectroscopy [118], and ellipsometry [120]. Tin dioxide as well as gold can be also modified using this method [121, 122].

Interesting data on modification of gold surfaces by molecularly-imprinted polymers are presented in
[123]. The authors described formation of hydrophobic self-assembled molecularly-imprinted monolayers of hexadecanthiol and developed a sensor system for cholesterol detection on their basis. The developed amperometric sensor system was found to be selective to cholesterol as compared to its close structural analogues (cholic and deoxycholic acids), while kinetics of the sensor responses was quite fast (the time of the sensor response comprised 5 min only). Unfortunately, the sensor demonstrated poor storage stability and lost $60 \%$ of its initial sensitivity after 10 days of storage. That was a limitation for its wide practical application in medical diagnostics.

Significantly much more effective approach based on modification of golden electrodes by thin layers of molecularly-imprinted polymers using the method of grafting polymerization was developed recently [98, 124-126]. The highly cross-linked structure of molecularly-imprinted polymers provided highly-selective recognition of analytes (triazine herbicides), while sensor responses remained stable for a long time (approximately 1 year).

Imprinted silica gels. Application of silica-gels in molecular imprinting was pioneered by Dickey, the first who synthesized substrate-selective adsorbents capable of selective recognition of dyes [127-129]. The imprinted material with the increased affinity to the template molecule was obtained by precipitation of silica-gels in the presence of methyl orange. Silica gels were also imprinted by other template molecules and used for separation of enantiomers [130-132], pesticides [133, 134], and drugs [135]. The materials synthesized in this way were not stable and quickly lost their selectivity. Therefore, this direction was not further proceeded. Moreover, a significant disadvantage of this approach is impossibility of selective silica gel synthesis towards water-insoluble substances, while Partikeev's method of synthesis of silica gels from organogels was found to be ineffective [133].

Molecularly-imprinted composite inorganic materials. This approach is a continuation of Dikey's papers [127-128]. It is based on synthesis [of] highly-cross-linked polysiloxanes on the surface of silica gel particles. The polycondensation reaction takes place in the presence of silanes having functional groups able to interact with template molecules. This 
approach is similar to the above-mentioned one, where polymerizable double-bonds are replaced with silane groups capable of polycondensation. A number of works on application of cross-linked polysiloxanes for selective recognition of dyes [136], glycoproteins [114], and NAD [137] were published.

Bioimprinting. The method of molecular imprinting is applicable not only for synthetic polymers, but also for biopolymers [1, 138]. So-called bioimprinting was developed for producing enzymatic activity/substrate selectivity/change of enzymatic activity in proteins $[139,140]$, for producing enantioselectivity [141], as well as for retention of protein receptor properties in organic solvents $[141,142]$. Usually, partly denaturated protein undergoes interaction with a template molecule, while its structure is stabilized by bi-functional cross-linkers. Using this approach enzymatic activity can be produced in proteins (albumin, concavanin A), enzymatic activity of ribonuclease, glucoseoxidase, urease, $\alpha$-amylase can be changed, while their stability can be increased [143-145].

Another approach to bioimprinting proteins is based on their ability to retain "structural memory" after the transfer from aqueous to anhydrous environment. In the case of precipitation or liophilization of a the protein from aqueous environment in the presence of a template molecule, the latter can further demonstrate predictable changes of its properties in organic solvents [146-157], and (under condition of additional stabilization) in aqueous solutions [158]. Synthetic receptor sites can be also formed using the method of molecular imprinting in cross-linked carbohydrates starch [159] and amylase [160, 161]. Using this approach, polymers capable of selective recognition of methylene blue [159], and glucose [160, 161] were obtained.

All the methods described in the present review give a possibility to obtain synthetic mimics of biological receptors with different selectivity, since all of them under certain conditions provide formation of complexes between templates and functional groups on the surface of polymers as well as accessibility of the selective sites due to formation of porous structure.

In author's opinion, molecularly imprinted polymers due to their selectivity under recognition of template molecules and stability in harsh environments are much more promising material as to their practical application in current analytical chemistry and biotechnology (including sensor technology) as compared to than traditional biomolecules. One of the attractive features of these materials is a possibility of synthesis of inexpensive artificial receptors to virtually unlimited number of substances. Synthesis of MIPs towards substances which have no natural receptors or synthesis of natural receptors to which is problematic (low-molecular weight compounds, mycotoxins, bacterial toxins, etc.) is of special interest. From this point of view application of the methods of computational modeling, providing fast optimization of artificial receptors' composition able to bind effectively target analytes is of special interest. Highly cross-linked organic polymers with stable physicochemical characteristics obtained in the form of both polymeric particles and thin films seem to be the most promising to be used in current biotechnology. The analysis of literature data demonstrates effectiveness of application of polymers-biomimics for both fundamental investigations of molecular recognition processes and practical applications.

Financial support from National Academy of Sciences of Ukraine (programs "Sensor systems for medical-ecological and industri al purposes" and "Novel medical-biological problems and human environment")

\section{T. А. Сергеєва}

Молекулярно-імпринтовані полімери як штучні аналоги біологічних рецепторів. 1. Загальні принципи молекулярного імпринтингу

Резюме

Огляд присвячено аналізу робіт у галузі отримання штучних аналогів біологічних рецепторів із застосуванням методу молекулярного імпринтингу. Розглянуто загальні принципи зазначеного методу та типи полімерів, які одержують із його використанням. Основну увагу приділено полімерам- біоміметикам, синтезованим методом нековалентного молекулярного імпринтингу.

Ключові слова: молекулярний імпринтинг, молекулярно-імпринтовані полімери, полімери-біоміметики. 


\section{T. А. Сергеева}

Молекулярно-импринтированные полимеры как искусственные аналоги биологических рецепторов. 1. Принципы молекулярного импринтинга

\section{Резюме}

Обзор посвящен анализу работ в области получения синтетических аналогов биологических рецепторов с использованием метода молекулярного импринтинга. Рассмотрены общие принцииы указанного метода и типы полимеров, получаемые при его использовании. Особое внимание уделено полимерам-биомиметикам, синтезированным методом нековалентного молекулярного импринтинга.

Ключевые слова: молекулярный импринтинг, молекулярно-импринтированные полимеры, полимеры-биомиметики.

\section{REFERENCES}

1. Wulff $G$. Molecular imprinting in cross-linked materials with the aid of molecular templates - a way towards artificial antibodies // Angew. Chem. Int. Ed. Engl.-1995.-34.-P. 18121832.

2. Sellergren B. Molecular imprinting by noncovalent interactions. Enantioselectivity and binding capacity of polymers prepared under conditions favoring the formation of template complexes // Makromol. Chem.-1989.-190.-P. 2703-2711.

3. Sellergren B. Molecular imprinting by noncovalent interactions: tailor-made chiral stationary phases of high selectivity and sample load capacity // Chirality.-1989.-1.-P. 6368.

4. Sellergren B., Lepisto M., Mosbach K. Highly Enantioselective and substrate-selective polymers obtained by molecular imprinting utilizing noncovalent interactions. NMR and chromatographic studies on the nature of recognition // J. Amer. Chem. Soc.-1988.-110, N 17.-P. 58535860 .

5. Svenson J., Nicholls I. A. On the thermal and chemical stability of molecularly imprinted polymers // Anal. Chim. Acta.2001.-435, N 1.-P. 19-24.

6. Wulff G., Sarhan A. Uber die anwendung von enzymanalog gebauten polymeren zur racemattrennung // Angew. Chem.1972.-84, N 8.-P. 364.

7. Wulff G., Sarhan A., Gimpel J., Lohmar E. Uber enzymanalog gebaute polymere, III) Zur synthese von polymerisierbaren D-Glycerins дurenderivaten // Chem. Ber.-1974.-107.P. 3364-3376.

8. Wulff G., Sarhan A., Zabrocki K. Enzyme-analogue built polymers and their use for the resolution of racemates // Tetrahed. Lett.-1973.-44.-P. 4329-4332.
9. Wulff G., Schulze I. 9. Enzyme-analogue built polymers. IX. Polymers with mercapto groups of definite cooperativity // Isr. J. Chem.-1978.-17.-P. 291-297.

10. Wulff G., Schulze I. Gezielte kooperativitдt sowie vereinzelung von mercaptogruppen in syntetischen polymeren // Angew. Chem.-1978.-90.-P. 568-570.

11. Wulff G., Schulze I., Zabrocki K., Vesper W. Uber enzymanalog gebaute polymere, 11) Bindungsstellen im polymer mit unterschiedlicher zahl der haftgruppen // Makromol. Chem.-1980.-181.-P. 531-544.

12. Wulff G., Vesper R., Grobe-Einsler R., Sarhan A. Enzymeanalogue built polymers, 4) On the synthesis of polymers containing chiral cavities and their use for the resolution of racemates // Makromol. Chem.-1977.-178.-P. 2799-2816.

13. Wulff G., Vesper $W$. Preparation of chromatographic sorbents with chiral cavities for racemic resolution // J. Chromatogr.1978.-167.-P. 171-186.

14. Andersson L., Ekberg B., Mosbach K. Synthesis of a new amino acid based cross-linker for preparation of substrate selective acrylic polymers // Tetrahed. Lett.-1985.-26, N 30.P. 3623-3624.

15. Andersson L., Sellergren B., Mosbach K. Imprinting of amino acid derivatives in macroporous polymers // Tetrahed. Lett.1984.-25, N 45.-P. 5211-5214.

16. Arshady R., Mosbach K. Synthesis of substrate-selective polymers by host-guest polymerization // Makromol. Chem.1981.-182.-P. 687-692.

17. Norrlow O., Glad M., Mosbach K. Acrylic polymer preparations containing recognition sites obtained by imprinting with substrates // J. Chromatogr.-1984.-299.-P. 29-41.

18. Sellergren B., Ekberg B., Mosbach K. Molecular imprinting of amino acid derivatives in macroporous polymers // J. Chromatogr.-1985.-347.-P. 1-10.

19. Ansell R. J., Ramstrom O., Mosbach K. Artificial antibodies prepared by molecular imprinting // Clin. Chem.-1996.-42, N 9.-P. 1506-1512.

20. Muldoon M. T., Stanker L. H. Plastic antibodies: Molecularly imprinted polymers // Chem. Ind.-1996.-18.-P. 204-207.

21. Klein J. U., Whitcombe M. J., Mulholland F., Vulfson E. N. Template-mediated synthesis of a polymeric receptor specific to amino acid sequences // Angew. Chem. Int. Ed. Engl.1999.-38.-P. 2057-2060.

22. Bereczki A., Tolokan A., Horvai G., Horvath V., Lanza F., Hall A. J., Sellergren B. Determination of phenytoin in plasma by molecularly imprinted solid-phase extraction // J. Chromatogr. A.-2001.-930, N 1-2.-P. 31-38.

23. Quaglia M., Chenon K., Hall A. J., De Lorenzi E., Sellergren $B$. Target analogue imprinted polymers with affinity for folic acid and related compounds // J. Amer. Chem. Soc.-2001.123, N 10.-P. 2146-2154.

24. Blomgren A., Berggren C., Holmberg A., Larsson F., Sellergren $B$., Ensing $K$. Extraction of clenbuterol from calf urine using a molecularly imprinted polymer followed by quantitation by high-performance liquid chromatography with UV detection // J. Chromatogr. A.-2002.-975.-P. 157-164.

25. Vlatakis G., Andersson L. I., Muller R., Mosbach K. Drug assay using antibody mimics made by molecular imprinting // Nature.-1993.-361.-P. 645-647.

26. Andersson L. I., Muller R., Vlatakis G., Mosbach K. Mimics of the binding sites of opioid receptors obtained by molecular imprinting of enkephalin and morphine // Proc. Nat. Acad. Sci. USA.-1995.-92.-P. 4788-4792.

27. Kriz D., Mosbach K. Competitive amperometric morphine sensensor based on an agarose immobilized molecularly 
imprinted polymer // Anal. Chim. Acta.-1994.-300, N 1-3.P. 71-75.

28. Piletska E. V., Romero-Guerra M., Chianella I., Karim K., Turner A. P. F., Piletsky S. A. Towards the development of multisensor for drugs of abuse based on molecular imprinted polymers // Anal. Chim. Acta.-2005.-542.-P. 111-117.

29. Tamayo F. G., Martin-Esteban A. Selective high performance liquid chromatography imprinted-stationary phases for the screening of phenylurea herbicides in vegetable samples // J. Chromatogr. A.-2005.-1098.-P. 116-122.

30. Tamayo F. G., Casillas J. L., Martin-Esteban A. Evaluation of new selective molecularly imprinted polymers prepared by precipitation polymerisation for the extraction of phenylurea herbicides // J. Chromatogr. A.-2005.-1069.-P. 173-181.

31. Tamayo F. G., Titirici M. M., Martin-Esteban A., Sellergren $B$. Synthesis and evaluation of new propazine-imprinted polymer formats for use as stationary phases in liquid chromatography // Anal. Chim. Acta.-2005.-542.-P. 38-46.

32. Sergeyeva T. A., Brovko O. O., Piletska E. V., Piletsky S. A., Goncharova L. A., Karabanova L. V., Sergeyeva L. M., El'skaya A. V. Porous molecularly imprinted polymer membranes and polymeric particles // Anal. Chim. Acta.-2007.582, N 2.-P. 311-319.

33. Sergeyeva T. A., Piletsky S. A., Brovko A. A., Slinchenko E. A., Sergeeva L. M., Panasyuk T. L., Elskaya A. V. Conductometric sensor for atrazine detection based on molecularly imprinted polymer membranes // Analyst.-1999.-124, N 3.P. 331-334.

34. Sergeyeva T. A., Piletsky S. A., Brovko A. A., Slinchenko E. A., Sergeeva L. M., Elskaya A. V. Selective recognition of atrazine by molecularly imprinted polymer membranes. Development of conductometric sensor for herbicides detection // Anal. Chim. Acta.-1999.-392, N 2-3.-P. 105-111.

35. Sergeyeva T. A., Matuschewski H., Piletsky S. A., Bendig J., Schedler U., Ulbricht M. Molecularly imprinted polymer membranes for substance-selective solid-phase extraction from water by surface photo-grafting polymerization // J. Chromatogr. A.-2001.-907, N 1-2.-P. 89-99.

36. Sergeyeva T. A., Piletsky S. A., Piletska E. V., Brovko O. O., Karabanova L. V., Sergeeva L. M., El'skaya A. V., Turner A. $P$. F. In situ formation of porous molecularly imprinted polymer membranes // Macromolecules.-2003.-36.-P. 73527357.

37. Weiss R., Freudenschuss M., Krska R., Mizaikoff B. Improving methods of analysis for mycotoxins: molecularly imprinted polymers for deoxynivalenol and zearalenone // Food Addit. Contam.-2003.-20.-P. 386-395.

38. Chianella I., Lotierzo M., Piletsky S. A., Tothill I. E., Chen B., Karim K., Turner A. P. F. Rational design of a polymer specific for microcystin-LR using a computational approach // Anal. Chem.-2002.-74, N 6.-P. 1288-1293.

39. Sergeyeva T. A., Piletska O. V., Goncharova L. A., Brovko O. $O$., Piletsky S. A., El'ska G. V. Sensor system based on molecularly-imprinted polymer membranes for selective recognition of aflatoxin B1 // Ukr. Biokhim. Zhurn.-2008.-80, N 3.-P. 84-93.

40. Sergeyeva T. A., Piletska O. V., Brovko O. O., Goncharova L. A., Piletsky S. A., El'ska G. V. Aflatoxin-selective molecularly-imprinted polymer membranes based on acrylatepolyurethane semi-interpenetrating polymer networks // Ukr. Biokhim. Zhurn.-2007.-79, N 5.-P. 109-115.

41. Pogorelova S. P., Zayats M., Bourenko T., Kharitonov A. B., Lioubashevski O., Katz E., Willner I. Analysis of $\operatorname{HAD}(\mathrm{P})(+) /$ $\mathrm{NAD}(\mathrm{P}) \mathrm{H}$ cofactors by imprinted polymer membranes associated with ion-sensitive field-effect transistor devices and Au-quartz crystals // Anal. Chem.-2003.-75.-P. 509517.

42. Raitman O. A., Chegel V. I., Kharitonov A. B., Zayats M., Katz E., Willner I. Analysis of $\mathrm{NAD}(\mathrm{P})(+)$ and $\mathrm{NAD}(\mathrm{P}) \mathrm{H}$ cofactors by means of imprinted polymers associated with $\mathrm{Au}$ surfaces: A surface plasmon resonance study // Anal. Chim. Acta.-2004.-504.-P. 101-111.

43. Andersson L. I., Miyabayashi A., O'Shannessy D. J., Mosbach $K$. Enantiomeric resolution of amino acid derivatives on molecularly imprinted polymers as monitored by potentiometric measurements // J. Chromatogr. A.-1990.-516.P. 323-331.

44. Andersson L. Preparation of amino acid ester-selective cavities formed by non-covalent imprinting with a substrate in highly cross-linked polymers // React. Polym.-1988.-9.P. 29-41.

45. Wulff G., Vietmeier J. Enzyme-analogue built polymers, 26) Enantioselective synthesis of amino acids using polymers possessing chiral cavities obtained by an imprinting procedure with template molecules // Makromol. Chem.1989.-190.-P. 1727-1735.

46. Piletsky S. A., Dubey Ya. I., Fedoryak D. M., Kukhar V. P. Substrate-selective polymer membranes. Selective transfer of nucleic acids' components // Biopolymers and Cell.-1990.6, N 5.-P. 55-58.

47. Shea K. J., Spivak D. A., Sellergren B. Polymer complements to nucleotide bases. selective binding of adenine derivatives to imprinted polymers. // J. Amer. Chem. Soc.-1993.-115.P. 3368-3369.

48. Spurlock L. D., Jaramillo A., Praserthdam A., Lewis J., Brajtertoth $A$. Selectivity and sensitivity of ultrathin purine templated overoxidized polypyrrole film electrodes // Anal. Chim. Acta.-1996.-336.-P. 37-46.

49. Wang L., Zhang $Z$. The study of oxidization fluorescence sensor with molecular imprinting polymer and its application for 6-mercaptopurine (6-MP) determination // Talanta.-2008.76, N 4.-P. 768-771.

50. Kugimiya A., Takeuchi T. Molecularly imprinted polymercoated quartz crystal microbalance for detection of biological hormone // Electroanalysis.-1999.-11, N 15.-P. 1158-1160.

51. Gao J. G., Zhou J., Qu X. J. Characteristics of molecular recognition of plant hormone $\mathrm{H}$-1-indole-3-acetic acid molecular template polymer // Chin. J. Anal. Chem.-2003.-31.P. 1173-1177.

52. Fujiwara, M., Nishiyama M., Yamamura I., Ohtsuki S., Nomura $R$. A sol-gel method using acetic anhydride in the presence of cholesterol in organic solution media: Preparation of silicas that recognize steroid hormones // Anal. Chem.2004.-76, N 8.-P. 2374-2381.

53. Kublickas R., Werner C., Jariene G., Voit B., Lasas L. Polyacrylamide gels containing ionized functional groups for the molecular imprinting of human growth hormone // Polym. Bull.-2007.-58, N 3.-P. 611-617.

54. Kubo T., Matsumoto H., Shiraishi F., Nomachi M., Nemoto $K$., Hosoya K., Kaya K. Selective separation of hydroxy polychlorinated biphenyls (HO-PCBs) by the structural recognition on the molecularly imprinted polymers: Direct separation of the thyroid hormone active analogues from mixtures // Anal. Chim. Acta.-2007.-589, N 2.-P. 180-185.

55. Wulff G., Minarmk M. Template imprinted polymers for HPLC separation of racemates // J. Liq. Chromatogr.- 1990.13, N 15.-P. 2987-3000. 
56. Wulff G., Schauhoff S. Racemic resolution of free sugars with macroporous polymers prepared by molecular imprinting. selectivity dependence on the arrangement of functional groups versus spatial requirements // J. Org. Chem.-1991.-56, N 1.-P. 395-400.

57. Yan S. L., Gao Z. X., Fang Y. J., Cheng Y. Y., Zhou H. Y., Wang $H$. $Y$. Characterization and quality assessment of binding properties of malachite green molecularly imprinted polymers prepared by precipitation polymerization in acetonitrile // Dyes Pigm.-2007.-74, N 3.-P. 572-577.

58. Gong S. L., Yu Z. J., Meng L. Z., Hu L., He. Y. B. Dye-molecular-imprinted polysiloxanes. II. Preparation, characterization, and recognition behaviour // J. Appl. Polymer Sci.2004.-93, N 2.-P. 637-643.

59. Gilliland J. W., Yokoyama K., Yip W. T. Solvent effect on mobility and photostability of organic dyes embedded inside silica sol-gel thin films // Chem. Mat.-2005.-17.-P. 67026712 .

60. Dunkin I. R., Lenfeld J., Sherrington D. C. Molecular imprinting of flat polycondensed aromatic molecules in macroporous polymers // Polymer.-1993.-34, N 1.-P. 77-84.

61. Dickert F. L., Forth P., Lieberzeit P., Tortschanoff M. Molecular imprinting in chemical sensing - detection of aromatic and halogenated hydrocarbons as well as polar solvent vapors // Fresenius J. Anal. Chem.-1998.-360, N 7.-P. 759-762.

62. Lubke M., Whitcombe M. J., Vulfson E. N. A novel approach to the molecular imprinting of polychlorinated aromatic compounds // J. Amer. Chem. Soc.-1998.-120.-P. 13342-13348.

63. Dickert F. L., Tortschanoff M., Bulst W. E., Fischerauer G. Molecularly imprinted sensor layers for the detection of polycyclic aromatic hydrocarbons in water // Anal. Chem.-1999.71, N 20.-P. 4559-4563.

64. Mukawa T., Goto T., Nariai H., Aoki Y., Imamura A., Takeuchi $T$. Novel strategy for molecular imprinting of phenolic compounds utilizing disulfide templates // J. Pharm. Biomed. Anal.-2003.-30.-P. 1943-1947.

65. Yu K. Y., Tsukaghoshi K., Maeda M., Takagi M. Metal ionimprinted microspheres prepared by reorganization of the coordinating groups of the surface // Anal. Sci.-1992.-8.P. 701-703.

66. Tsukagoshi K., Yu. K., Maeda M., Takagi M. Adsorption behavior of metal-ions onto $\mathrm{Co}(\mathrm{II})$-imprinted microspheres prepared by surface imprinting - Effect of $\mathrm{Co}(\mathrm{II})$-imprinting // Kobunshi Ronbunshu.-1993.-50, N 5.-P. 455-458.

67. Ersoz A., Say R., Denizli A. Ni(II) ion-imprinted solid phase extraction and preconcentration in aqueous solutions by packed-bed columns // Anal. Chim. Acta.-2004.-502.-P. 9197.

68. Daniel S., Rao P. P., Rao T. P. Investigation of different polymerization methods on the analytical performance of palladium(II) ion imprinted polymer material // Anal. Chim. Acta.-2005.-536.-P. 197-206.

69. Koide Y., Senba H., Shosenji H., Maeda M., Takagi M. Selective adsorption of metal ions to surface-template resins prepared by emulsion polymerization using 10-(p-vinylphenyl)decanoic acid // Bull. Chem. Soc. Jap.-1996.-69, N 1.-P. 125-130.

70. Koide Y., Tdujimoto K., Shosenji H., Maeda M. Adsorption of metal ions to surface-template resins prepared with amphiphilic styrene monomers bearing amino carboxylic acid // Bull. Chem. Soc. Jap.-1998.-71, N 4.-P. 789-796.

71. Koide Y., Shosenji H., Maeda M., Takagi M. Selective adsorption of metal ions to surface-templated resins prepared by emulsion polymerization using a functional surfactant // ACS Symp. Ser.-1998.-703.-P. 264-277.

72. Dai S., Burleigh M. C., Ju Y. H., Gao H. J., Lin J. S., Pennycook S. J., Barnes C. E., Xue Z. L. Hierarchically imprinted sorbents for the separation of metal ions // J. Amer. Chem. Soc.-2000.-122, N 5.-P. 992-993.

73. Asanuma H., Kajiya K., Hishiya T., Komiyama M. Molecular imprinting of cyclodextrin in water for the recognition of peptides // Chem. Lett.-1999.-7.-P. 665-666.

74. Rachkov A., Minoura N. Recognition of oxytocin and oxytocin-related peptides in aqueous media using a molecularly imprinted polymer synthesized by the epitope approach // J. Chromatogr. A.-2000.-889, N 1-2.-P. 111-118.

75. Hart B. R., Shea K. J. Synthetic peptide receptors: Molecularly imprinted polymers for the recognition of peptides using peptide-metal interactions // J. Amer. Chem. Soc.-2001.123, N 9.-P. 2072-2073.

76. Hart B. R., Shea K. J. Molecular imprinting for the recognition of $\mathrm{N}$-terminal histidine peptides in aqueous solution // Macromolecules.-2002.-35, N 16.-P. 6192-6201.

77. Andersson L. I., Muller R., Mosbach K. Molecular imprinting of the endogenous neuropeptide Leu-5-enkephalin and some derivatives thereof // Macromol. Res. Communs.-1996.-17, N 1.-P. 65-71.

78. Lin C. C., Wang G. R., Liu C. Y. A novel monolithic column for capillary electrochromatographic separation of oligopeptides // Anal. Chim. Acta.-2006.-572, N 2.-P. 197-204.

79. Braco L., Dabulis K., Klibanov A. M. Production of abiotic receptors by molecular imprinting of proteins // Proc. Nat. Acad. Sci. USA.-1990.-87.-P. 274-277.

80. Lin H. Y., Hsu C. Y., Thomas J. L., Wang S. E., Chen H. C., Chou T. C. The microcontact imprinting of proteins: The effect of cross-linking monomers for lysozyme, ribonuclease A and myoglobin // Biosensors and Bioelectronics.-2006.-22, N 4.-P. 534-543.

81. Lu S. L., Cheng G. X., Pang X. S. Study on preparation of protein-imprinted soft-wet gel composite microspheres with magnetic susceptibility and their characteristics. I. Preparation and particle morphology // J. Appl. Polym. Sci.-2006.100.-P. 684-694.

82. Matsunaga T., Takeuchi T. Crystallized protein-imprinted polymer chips // Chem. Lett.-2006.-35, N 9.-P. 1030-1031.

83. Kimhi O., Bianco-Peled H. Study of the interactions between protein-imprinted hydrogels and their templates // Langmuir.-2007.-23, N 11.-P. 6329-6335.

84. Brown M. E., Puleo D. A. Protein binding to peptide-imprinted porous silica scaffolds // Chem. Eng. J.-2008.-137, N 1.-P. 97-101.

85. Alexander C., Vulfson E. N. Spatially-functionalized polymer surfaces produced by cell-mediated lithography // Adv. Mater.-1997.-9.-P. 751-755.

86. Dickert F. L., Hayden O., Halikias K. P. Synthetic receptors as sensor coatings for molecules and living cells // The Analyst.-2001.-126, N 6.-P. 760-771.

87. Dickert F. L., Hayden O., Lieberzeit P., Haderspoeck C., Bindeus R., Palfinger C., Wirl B. Nano- and micro-structuring of sensor materials - from molecule to cell detection // Synth. Met.-2003.-138.-P. 65-69.

88. Takatsy A., Kilar A., Kilar F., Hjerten S. Universal method for synthesis of artificial gel antibodies by the imprinting approach combined with a unique electrophoresis technique for detection of minute structural differences of proteins, viruses and cells (bacteria): I. Gel antibodies against proteins (transferrins) // J. Sep. Sci.-2006.-29, N 18.-P. 2802-2809. 
89. D'Souza S. M., Alexander C., Carr S. W., Waller A. M., Whitcombe M. J., Vulfson E. N. Directed nucleation of calcite at a crystal-imprinted polymer surface // Nature.-1999.-398, N 6725.-P. 312-316.

90. D'Souza S. M., Alexander C., Whitcombe M. J., Waller A. M., Vulfson E. N. Control of crystal morphology via molecular imprinting // Polym. Int.-2001.-50, N 4.-P. 429-432.

91. Wang J. F., Zhou L. M., Liu X. L., Wang Q. H., Zhu D. Q. Effect of functional monomer on chiral separation ability of molecular imprinted chiral stationary phase // Acta Chim. Sin. $-2000 .-58$, N 3.-P. 351-355.

92. Lanza F., Hall A. J., Sellergren B., Bereczki A., Horvai G., Bayoudh S., Cormack P. A. G., Sherrington D. C. Development of a semiautomated procedure for the synthesis and evaluation of molecularly imprinted polymers applied to the search for functional monomers for phenytoin and nifedipine // Anal. Chim. Acta.-2001.-435, N 1.-P. 91-106.

93. Zhang L. Y., Cheng G. X., Fu C., Liu X. H. Tyrosine imprinted polymer beads with different functional monomers via seed swelling and suspension polymerization // Polym. Eng. Sci.2003.-43.-P. 965-974.

94. Takeuchi T., Fukuma D., Matsui J. Combinatorial molecular imprinting: an approach to synthetic polymer receptors // Anal. Chem.-1999.-71.-P. 285-290.

95. Lanza F., Sellergren B. Method for synthesis and screening of large groups of molecularly imprinted polymers // Anal. Chem.-1999.-71, N 11.-P. 2092-2096.

96. Yilmaz E., Mosbach K., Haupt K. Influence of functional and cross-linking monomers and the amount of template on the performance of molecularly imprinted polymers in binding assays // Anal. Comm.-1999.-36, N 5.-P. 167-170.

97. Subramanyam S., Piletsky S. A., Piletska E. V., Chen B., Karim K., Turner A. P. F. «Bite-and-switch» approach using computationally designed molecularly imprinted polymers for sensing of creatinine // Biosensors and Bioelectronics.2001.-16.-P. 631-637.

98. Sergeyeva T. A., Panasyuk-Delaney T. L., Piletska O. V., Piletsky S. A., El'ska G. V. Development of a capacitive sensor for environmental monitoring based on thin films of molecularly-imprinted polymers. Computational modeling for optimization of the composition of synthetic mimics of bioreceptors // Ukr. Biokhim. Zhurn.-2006.-78, N 2.- P. 121-131.

99. Sergeyeva T. A., Piletska O. V., Piletsky S. A., Sergeeva L. M., Brovko O. O., El'ska G. V. Data on the structure and recognition properties of the template-selective binding sites in semi-IPN-based molecularly imprinted polymer membranes // Mater. Sci. Eng. C.-2008.-28.-P. 1471-1479.

100. O'Shannessy D. J., Andersson L. I., Mosbach K. Molecular recognition in synthetic polymers. Enantiomeric resolution of amide derivatives of amino acids on molecularly imprinted polymers // J. Mol. Recogn.-1989.-2, N 1.-P. 1-5.

101. Andersson L. I., Mosbach K. Enantiomeric resolution on molecularly imprinted polymers prepared with only noncovalent and non-ionic interactions // J. Chromatogr.1990.-516.-P. 313-322.

102. Sellergren B., Shea K. J. Influence of polymer morphology on the ability of imprinted network polymers to resolve enantiomers // J. Chromatogr.-1993.-635.-P. 31-49.

103. Wulff G., Poll H. G., Minarik M. Enzyme-analogue built polymers. XIX. Racemic resolution on polymers containing chiral cavities // J. Liq. Chromatogr.-1986.-9.-P. 385-405.

104. Hart B. R., Rush D. J., Shea K. J. Discrimination between enantiomers of structurally related molecules: Separation of benzodiazepines by molecularly imprinted polymers // J. Amer. Chem. Soc.-2000.-122, N 3.-P. 460-465.

105. Piletsky S. A., Karim K., Piletska E. V., Day C. J., Freebairn $K$. W., Legge C., Turner A. P. F. Recognition of ephedrine enantiomers by molecularly imprinted polymers designed using a computational approach // Analyst.-2001.-126, N 10.-P. 1826-1830.

106. Machtejevas E., Sellergren B., Martynaitis V., Owens P. K., Maruska A. Screening of oxazepine indole enantiomers by means of high performance liquid chromatography with imprinted polymer stationary phase // J. Sep. Sci.-2004.-27, N 7-8.-P. 547-551.

107. Yang G. L., Yin J. F., Li Z. W., Liu H. Y., Cai L. P., Wang D. $X$., Chen $Y$. Chiral separation of nateglinide and its (L) enantiomer on a molecularly imprinted polymer-based stationary phase // Chromatographia.-2004.-59.-P. 705-708.

108. Guerreiro A. R., Korkhov V., Mijangos I., Piletska E. V., Rodins J., Turner A. P. F., Piletsky S. A. Influence of continuous magnetic field on the separation of ephedrine enantiomers by molecularly imprinted polymers // Biosensors and Bioelectronics.-2008.-23, N 7.-P. 1189-1194.

109. Panasyuk T. L., Mirsky V. M., Piletsky S. A., Wolfbeis O. S. Electropolymerized molecularly imprinted polymers as receptor layers in a capacitive chemical sensors // Anal. Chem.-1999.-71.-P. 4609-4613.

110. Piletsky S. A., Piletska E. V., Chen B., Karim K., Weston D., Barret G., Lowe P., Turner A. P. F. Chemical grafting of molecularly imprinted homopolymers to the surface of microplates. Application of artificial adrenergic receptor in enzyme-linked assay for beta-agonists determination // Anal. Chem.-2000.-72.-P. 4381-4385.

111. Malitesta C., Losito I., Zambonin P. G. Molecularly imprinted electrosynthesized polymers: new materials for biomimetic sensors // Anal. Chem.-1999.-71.-P. 1366-1370.

112. Deore B., Chen Z. D., Nagaoka T. Overoxidised polypyrrole with dopant complementary cavities as a new molecularly imprinted polymer matrix // Anal. Sci.-1990.-15, N 9.P. 827-828.

113. Chen Z. D., Takei Y., Deore B. A., Nagaoka T. Enantioselective uptake of amino acid with overoxidized polypyrrole colloid templated with L-lactate // Analyst.-2000.-125, N 12.-P. 2249-2254.

114. Glad M., Kempe M., Mosbach K. Selective affinity material, preparation thereof by molecular imprinting, and use of the same // PCT Int. Application WO9305068, 1993.

115. Arnold F., Plunkett S., Dhal P. K., Vidyasankar S. Surface modification with molecularly-imprinted polymers for selective recognition // Polymer Preprints.-1995.-36.-P. 97-98.

116. Prasad B. B., Banerjee S. Preparation, characterization and performance of a silica gel bonded molecularly imprinted polymer for selective recognition and enrichment of $\beta$-lactam antibiotics // React. and Funct. Polymers.-2003.-55.-P. 159169.

117. Sagiv J. Organized monolayers by adsorption. III. Irreversible adsorption and memory effects in skeletonized silane monolayers // Isr. J. Chem.-1979.-18.-P. 346-353.

118. Kim J.-L., Cotton T. M., Uphaus R. A. Molecular recognition in monolayers and species detection by surface-enhanced resonance Raman spectroscopy // Thin Solid Films.-1988.160.-P. 389-397.

119. Kim J.-L., Cotton T. M., Uphaus R. A. Electrochemical and Raman characterization of molecular recognition sites in selfassembled monolayers // J. Phys. Chem.-1988.-92.-P. 55755578 . 
120. Andersson L. I., Mandenius C. F., Mosbach K. Studies on guest selective molecular recognition on an octadecyl silylated silicon surface using ellipsometry // Tetrahed. Lett.-1988.29.-P. 5437-5440.

121. Yamamura K., Hatakeyama H., Naka K., Tabushi I., Kurihara $K$. Guest selective molecular recognition by an octadecylsilyl monolayer covalently bound to an $\mathrm{SnO}_{2}$ electrode // J. Chem. Soc. Chem. Commun.-1988.-N 2.-P. 79-81.

122. Tabushi I., Kurihara K., Naka K., Yamamura K., Hatakeyama $H$. Supramolecular sensor based on $\mathrm{SnO}_{2}$ electrode modified with octadecylsilyl monolayer having molecular binding sites // Tetrahed. Lett.-1987.-28.-P. 4299-4202.

123. Piletsky S. A., Piletska E. V., Sergeyeva T. A., Panasyuk T. L., El'skaya A. V. Molecularly-imprinted self-assembled films with specificity to cholesterol // Sensors and Actuators B.-1999.-60.-P. 216-220.

124. Panasyuk-Delaney T., Mirsky V., Sergeyeva T., Wolfbeis O. Impedometric chemosensors based on thin film polymers // Proc. of the $4^{\text {th }}$ Int. Workshop on Applied Physics of Condensed Matter (Demanovska Dolina, Slovak Republic, September 17-19, 2001).-Demanovska Dolina, 2001.-P. 109202.

125. Panasyuk-Delaney T., Mirsky V. M., Wolfbeis O. S. Capacitive creatinine sensor based on a photografted molecularly imprinted polymer // Electroanalysis.-2002.-14, N 3.P. 221-224,

126. Delaney T. L., Zimin D., Rahm M., Weiss D., Wolfbeis O. S., Mirsky V. M. Capacitive detection in ultrathin chemosensors prepared by molecularly imprinted grafting photopolymerization // Anal. Chem.-2007.-79, N 8.-P. 3220-3225.

127. Dickey F. H. Preparation of specific adsorbents // Proc. Nat. Acad. Sci. USA.-1949.-35.-P. 227-229.

128. Dickey F. H. Specific adsorbtion // J. Phys. Chem.-1955.59, N 8.-P. 695-707.

129. Strelko V. V., Kanniblotskii V. A., Vysotskii Z. Z. Chemical adsorption of dyes on silica gels // Zhurn. Fizichesk. Khim.1968.-42.-P. 1219-1223.

130. Curti R., Colombo U. Separazione degli antipodi ottici dell'acido canfosolfonico mediante cromatografia su assorbenti specifici // Chim. Ind.-1951.-23, N 2.-P. 103.

131. Beckett A. H., Andersson P. A method for the determination of the configuration of organic molecules using «stereoselective adsorbents» // Nature.-1957.-179.-P. 1074-1075.

132. Erlenmeyer $H$., Bartels $H$. Uber das problem der ahnlichkeit in der chemie. Dunnschichtchromatographie mit spezifisch adsorbierenden silikagelen I // Helv. Chim. Acta.-1964.-47, N 46-51.-P. 1285-1288.

133. Patrikeev V. V., Sholin A. F. Methods of preparation and properties of specially formed silica gels and their use for separation of complex organic systems // Molek. Khromatogr.1964.-P. 66-72.

134. Kosmaty E. S., Chebot'ko K. A., Kanniblotskii V. A., Galinskaya V. I., Lukashevich O. V., Strelko V.V. Application of a selective adsorbent for DDT determination in aqueous solutions // Zhurn. Analit. Khim.-1975.-30, N 5.-P. 10271030.

135. Beckett A. H., Andewrson P. The determination of the relative configuration of morphine, levorphanol, and levophenazocine by stereoselective absorbents // J. Pharmacy and Parmacol.-1960.-12.-P. 228-236.

136. Glad M., Norrlow O., Sellergren B., Siegbahn N., Mosbach $K$. Use of silane monomers for molecular imprinting and enzyme entrapment in polysiloxane-coated porous silica // J. Chromatogr.-1985.-347.-P. 11-23.
137. Norrlow O., Mansson M. O., Mosbach K. Improved chromatography: prearranged distances between boronate groups by the molecular imprinting approach // J. Chromatogr.-1987.396.-P. 374-377.

138. Ratner B. D., Shi H. Q. Recognition templates for biomaterials with engineered bioreactivity // Curr. Opin. Solid State and Mater. Sci.-1999.-4, N 4.-P. 395-402.

139. Johansson A., Mosbach K., Mansson M.-O. Horse liver alcohol dehydrogenase can accept NADP+ as coenzyme in high concentrations of acetonitrile // Eur. J. Biochem.-1995.227.-P. 551-555.

140. Rich J. O., Dordick J. S. Controlling subtilisin activity and selectivity in organic media by imprinting with nucleophilic substrates. // J. Amer. Chem. Soc.-1997.-119.-P. 32453252 .

141. Stahl M., Jeppersson-Wistrand U., Mansson M.-O., Mosbach $K$. Induced stereoselectivity and substrate selectivity of bioimprinted $\alpha$-chymotrypsin in anhydrous organic media // J. Amer. Chem. Soc.-1991.-113.-P. 9366-9368.

142. Stahl M., Mansson M.-O., Mosbach K. The synthesis of a Damino acid ester in an organic media with $\alpha$-chymotrypsin modified by a bio-imprinting procedure // Biotechnol. Lett.1990.-12, N 3.-P. 161-166.

143. Saraswathi S., Keyes M. H. Semisynthetic «acid-esterase»: Conformational modification of ribonuclease // Enzyme and Microbial Technol.-1984.-6.-P. 98-100.

144. Liu J., Zhang K., Rena X., Luob G., Shen J. Bioimprinted protein exhibits glutathione peroxidase activity // Anal. Chim. Acta.-2004.-504.-P. 185-189.

145. Green B. S. Catalytic antibodies and biomimetics // Curr. Opin. Biotechnol.-1991.-2, N 3.-P. 395-400.

146. Vaidya A., Borck A., Manns A., Fischer L. Altering glucose oxidase to oxidize D-galactose through crosslinking of imprinted protein // ChemBioChem.-2003.-5, N 1.-P. 132135.

147. Dabulis K., Klibanov A. M. Molecular imprinting of proteins and other macromolecules resulting in new adsorbents // Biotechnol. Bioeng.-1992.-39, N 2.-P. 176-185.

148. Mosbach K., Ramstrom $O$. The emerging technique of molecular imprinting and its future impact of biotechnology // Bio/Technology.-1996.-14.-P. 163-170.

149. Mensson M.-O. Modification of enzymes and proteins with bioimprinting procedures // Adv. Mol. and Cell Biol.-1996.15, N 1.-P. 15-21.

150. Teke M., Sezginturk M. K., Dinckaya E., Telefoncu A. A bioimprinted urease biosensor: Improved thermal and operational stabilities // Talanta.-2008.-74, N 4.-P. 661-665.

151. Dabulis K., Klibanov A. M. Dramatic enhancement of enzymatic activity in organic solvents by lyoprotectants // Biotechnol. Bioeng.-1993.-41.-P. 566-571.

152. Russel A. J., Klibanov A. M. Inhibitor-induced enzyme activation in organic solvents // J. Biol. Chem.-1988.-263.P. 11624-11626.

153. Mingarro I., Abad C., Braco L. Interfacial activation-based molecular bioimprinting of lipolytic enzymes // Proc. Nat. Acad. Sci. USA.-1995.-92.-P. 3308-3312.

154. Gonzalez N. H., Braco L. Improving lipase activity in solvent-free media by interfacial activation-based molecular bioimprinting // J. Mol. Catal.-1997.-B3, N 1-4.-P. 11111119.

155. Mishra K., Griebenow K., Klibanov A. M. Structural basis for the molecular memory of imprinted polymers in anhydrous media // Biotechnol. Bioengn.-1996.-52, N 5.-P. 609-614. 
156. Klibanov A. M. Enzyme memory. What is remembered and why? // Nature.-1995.-374.-P. 596.

157. Lion-Dagan M., Willner I. Nitrospiropyran-modified $\alpha$-chymotrypsin, a photostimulated biocatalyst in an organic solvent: effects of bioimprinting // J. Photochem. and Photobiol. A: Chemistry.-1997.-108, N 2-3.-P. 247-252.

158. Peißker F., Fischer L. Crosslinking of imprinted proteases to maintain a tailor-made substrate selectivity in aqueous solutions // Bioorg. Med. Chem.-1999.-7.--P. 2231-2237.

159. Shinkai S., Yamada M., Sone T., Manabe O. Template synthesis from starch as an approach to tailor-made «Cyclodextrin»// Tetrahed. Lett.-1983.-24.-P. 3501-3504.
160. Wulff G., Kubik S. Helical amylose complexes with organic ligands // Makromol. Chem.-1992.-193.-P. 1071-1080.

161. Wulff G., Kubik S. Circular dichroism and UV-spectroscopy of complexes of amylose // Carbohydr. Res. 1992.-237.P. $1-10$.

UDC $577.1+573.6+543.393+543.556+004.942$

Received 24.03.09 